\title{
PEMBUDAYAAN AGAMA DALAM PEMBENTUKAN KARAKTER SISWA DI MTs NEGERI SLEMAN KOTA YOGYAKARTA
}

\author{
Fil Isnaeni \\ Program Studi Akuntansi, Universitas Pamulang \\ Email: dosen01086@unpam.ac.id
}

\begin{abstract}
Abstrak
Latar belakang penelitian adalah permasalahan moral yang terjadi di Indonesia yang berkaitan dengan karakter bangsa karena lunturnya nilai-nilai keagamaan yang tergeser dengan perkembangan zaman yang merusak moral peserta didik yang dapat merusak bangsa. Pendidikan berperan untuk membentuk karakter siswa yang baik. Madrasah Tsanawiyah Negeri Sleman Kota Yogyakarta melaksanakan pembudayaan agama guna membentuk karakter siswa yang baik. Penelitian ini diharapkan dapat memberi sumbangsih bagi dunia pendidikan dalam membekali peserta didiknya dengan karakter baik yang melekat dalam jiwa peserta didiknya dengan proses pembiasaan. Penelitian ini merupakan penelitian lapangan dengan menggunakan jenis penelitian analisis deskriptif kualitatif. Pengumpulan data yang digunakan dalam penelitian ini adalah pengamatan, wawancara, dan dokumentasi. Analisis data yang digunakan dalam penelitian ini dengen menelaah data, mereduksi data, pengkodean, mengadakan pemeriksaan keabsaan data dan menyimpulkan data dari fakta-fakta secara khusus kemudian disimpulkan secara umum.
\end{abstract}

Kata-kata kunci: Budaya agama dan pendidikan karakter

\begin{abstract}
The background of the research is the moral problems related to the the nation's characters that occur in Indonesia due to the erosion of religious values resulting from the change of times that is damaging the morale of the students and nation. Education plays a role in shaping student's good characters. Public Madrasah Tsanawiyah in Sleman, Yogyakarta cultivates religion to form student's good characters. This research is expected to contribute to the education in providing students with good characters inherent in the student's personality through the habituation process. It is a field research that uses a qualitative descriptive analysis. Research data are collected by observation, interview, and documentation. The data are analyzed by reviewing data, reducing data, coding, checking the validity of data and then drawing a general conclusion from the specifically-studied data.
\end{abstract}

Keywords: Religious culture and character education

\section{PENDAHULUAN}

Kemajuan perkembangan teknologi informasi yang kian hari semakin canggih, mengakibatkan mudahnya mengakses informasi dari manapun, tidak dipungkiri membawa dampak positif dan negatif. Serta arus globalisasi yang menyebabkan merosotnya penanaman nilai-nilai budaya dan agama. Mengerikan lagi akhir-akhir ini tindakan kriminal dengan menghalalkan segala cara, serta tindak asusila yang bukan merupakan hal yang tabu lagi didalam masyarakat yang dilakukan oleh oknum yang tidak bertanggung jawab. Fenomina demikian disebabkan oleh buruknya karakter bangsa, mulai hilangnya nilai moral, agama dan sosial di dalam masyarakat.

Pendidikan merupakan wadah yang sangat penting dalam membentuk karakter bangsa. Dalam UU No 20 tahun 2003 tentang sistem pendidikan Nasional pasal 3 yang berbunyi: pendidikan nasional berfungsi mengembangkan kemampuan dan membentuk karaker watak serta beradaban bangsa, bertujuan untuk mengembangkan potensi peserta didik agar menjaddi manusia yang beriman dan bertakwa kepada Tuhan Yang Maha Esa, berahklak mulia, 
sehat, berilmu, cakap, kreatif, mandiri, dan menjadi warga negara yang demokratis serta bertanggung jawab [1].

Dari singkat permasalahan tersebut Madrasah Tsanawiyah tampil dalam membina keagamaan sebagai ciri khas ke Islamannya, seperti menerapkan kegiatankegiatan harian, mingguan serta kegiatan hari besar agama Islam yang akan memupuk pembiasan terhadap peserta didiknya. Dengan upaya pembiasaan tersebut diharapkan Madrasah Tsanawiyah ini mampu membekali peserta didiknya kegiatan-kegiatan positif yang mampu melekat menjadi karakter positif terhadap siswanya. Proses pembudayaan agama tersebut bisa menjadi indikator keberhasilan pembentukan karakter positif terhadap peserta didik, misalnya dengan menerapkan pembiasaan kegiatan harian dengan membiasakan bersalam-salaman terhadap guru sebelum masuk lingkungan sekolah mampu menunjukan karakter religius terhadap siswa.

Menurut Koetjaningrat pembudayaan atau enkulturasi merupakan suatu proses seseorang individu mempelajari dan menyesuaiakn alam pikiran serta sikapnya dengan adat istiadat, sistem norma, dan oeraturan dalam kebudayaan [2]. Budaya diartikan sebagai keseluruhan sistem berfikir, nilai, moral norma dan keyakinan yang dihasilkanmasyarakat. Pembudayaan sam artinya dengan pembiasaan, dalam bermasyarakat yang berbudaya memerlukan sistem nilai, norma, dan keyakinan. Hasil dari interaksi manusia dengan sesamanya dan lingkunganya itu yang akan menghasilkan kebudayaan. Muhaimin menjelaskan budaya sekolah merupakan perpaduan nilai-nilai keyakinan, asumsi, pemahaman dan harapan-harapan yang diyakini oleh warga sekolah serta dijadikan pedoman bagi perilaku dan pemecahan masalah yang dihadapi. Dengan kata lain budaya sekolah merupakan semangat, sikap, dan perilaku pihak yang terkait dengan sekolah secara konsisten [3].

Manusia pada dasarnya memiliki dua potensi, yakni baik dan buruk. Di dalam AlQur'an surat AL-Araf ayat 179 yang berbunyi:

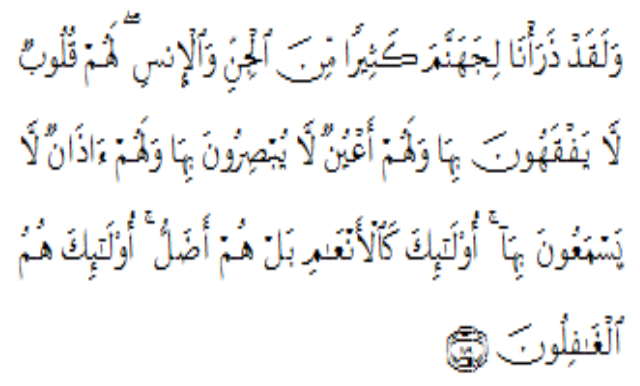

Artinya: dan Sesungguhnya Kami jadikan untuk (isi neraka Jahannam) kebanyakan dari jin dan manusia, mereka mempunyai hati, tetapi tidak dipergunakannya untuk memahami (ayat-ayat Allah) dan mereka mempunyai mata (tetapi) tidak dipergunakannya untuk melihat (tandatanda kekuasaan Allah), dan mereka mempunyai telinga (tetapi) tidak dipergunakannya untuk mendengar (ayat-ayat Allah). mereka itu sebagai binatang ternak, bahkan mereka lebih sesat lagi. mereka Itulah orang-orang yang lalai [4].

Dengan dua potensi tersebut menjadikan peserta didik memiliki kesempatan untuk menentukan dirinya menjadi baik ataupun buruk. Sikap manusia yang cenderung merujuk ke potensi negatif seperti sudat, bohong, menipu, sombong, congkak, riya', materialistik dan egois dapat menghancurkan diri sendiri dan memberikan energi negatif kepada setiap individu sehingga melahirkan manusia-manusia yang memiliki karakter buruk. Sebaliknya sikap jujur, rendah hati, qana'ah, dan bersikap positif lainnya cenderung mengarahkan manusia untuk memiliki hati yang baik, dan selalu bersikap positif maka dapat melahirkan manusia yang 
berkarakter baik. Berangkat dari latar belakang tersebut penulis tertarik untuk melakukan penelitian, bagaimana proses pembudayaan agama di MTsN Sleman Kota Yogyakarta dalam pembentukan karakter siswanya. Dan besar harapan penulis penelitian ini bermanfaat untuk pedoman pelaksanaan pembudayaan agama dalam madrasah maupun sekolah yang akan membekali siswanya menjadi pribadi yang berkarakter Walaupun penelitian mengenai pendidikan karakter dan budaya sekolah sudah ada, namun penelitian ini berbeda dengan penelitian yang sudah ada, karena penelitian ini akan mengupas tentang pembudayaan agama yang lebih khusus melalui pembiasaan pembentukan karakter siswanya melalui pembiasaan budaya sekolah.

\section{METODE}

Jenis penelitian ini merupakan penelitian kualitatif, yaitu penelitian lapangan dengan dasar penelitian naturalistik karena dilakukan pada kondisi yang alamiah [5]. Sifat penelitian ini deskriptif analitik. penelitian lapangan yang dilakukan secara terjun langsung guna memperoleh datadata yang diperlukan secara akurat. Jadi kunci dari penelitian kualitatif itu adalah peneliti itu sendiri, karena ia bertindak sebagai instrumen sekaligus pengumpul data, sedangkan instrumen selain manusia mempunyai fungsi terbatas yaitu hanya sebagai pendukung tugas peneliti.

Pendekatan yang digunakan dalam penelitian ini dengan menggunakan pendekatan fenomenologi yaitu menggunakan pengalaman hidup sebagai alat untuk memahami tentang inti pengalaman dari suatu fenomena yang dilakukan dengan memasuki wawasan persepsi informan dan melihat bagaimana mereka melalui suatu pengalaman kehidupan, serta memperlihatkan fenomena dan mencari makna dari pengalaman informan. Jenis pendekatan kualitatif yaitu salah satu pendekatan yang mengguanakan paradigma pengetahuan bedasarkan pandangan konstruktif yaitu suatu pengalaman individual, sosial, historis yang dibangun dengan maksud mengembangkan sebuah teori [5].

\section{Sumber data}

Dalam menentukan informan dilakukan dengan cara menggunakan teknik dengan cara menggunakan teknik purposive sampling dan snowball maksudnya peneliti menentukan sendiri sampel yang akan dijadikan informan yang sesuai dengan penelitian, yaitu:
a. Kepala MTsN Sleman Kota
b. Guru-guru MTsN Sleman Kota
c. Siswa MTsN Sleman Kota

2. Teknik Pengumpulan Data

Teknik dalam mengumpulkan data dengan cara observasi, wawancara mendalam dan dokumentasi.

3. Pemeriksaan keabsahan data

Dengan menggunakan teknik trianggulasi, dari sumber dan metode.

4. Teknik Analisis Data

a. Menelaah data yang berhasil dikumpulkan dari hasil wawancara, observasi dan dokumentasi.

b. Mengadakan reduksi data dengan cara mengambil data yang dapat diolah lebih lanjut.

c. Menyusun data dalam satuan yang relevan

d. Melakukan kategorisasi sambil melakukan pemgkodean

e. Mengadakan pemeriksaan keabsahan data melalui observasi tidak langsung dalam pemgamatan atas beberapa kelakuan dan kejadian yang kemudian dari hasil tersebut diambil benang merah 
yang menghubungkan antara hasil dokumentasi, observasi, dan wawancara yang merupakan data primer [6].

\section{HASIL DAN PEMBAHASAN}

Bentuk Pelaksanaan Pembudayaan Agama dalam Pembentukan Karakter Siswa di MTs Negeri Sleman Kota Yogyakarta.

Pembudayaan Agama merupakan sebuah proses dan usaha dalam menjalankan budaya sekolah dengan sikap, pengetahuan dan keterampilan, tradisi yang ada dalam madrasah, yang diupayakan mampu mendasari pembentukan karakter siswa. Pembudayaan agama di madrasah ini dijadikan sebagai ruhnya madrasah untuk meningkatkan spiritualitas madrasah ini.

\section{Pembudayaan agama melalui pembiasaan}

Pembiasaan budaya madrasah yang diterapkan merupakan salah satu upaya untuk menanamkan nilai-nilai karakter yang melakat pada diri siswa. Bentukbentuk pembiasaan yang dilaksanakan dilingkungan madrasah ini dilakukan melalui pengintergrasian kedalam kegiatan harian, mingguan dan tahunan.

a. Kegiatan harian

1) Mengucapkan salam dan berjabat tangan

Kegiatan ini dihidupkan oleh seluruh warga madrasah. Kegiatan ini dilakukan seluruh siswa ketika memasuki lingkungan madrasah. Kegiatan ini dilaksanakan rutin setiap hari dengan tujuan untuk melatih siswa agar tawadhu terhadap guru, serta melatih kedisiplinan siswa sehingga diharapkan akan melekat karakter disiplin dalam dirinya.

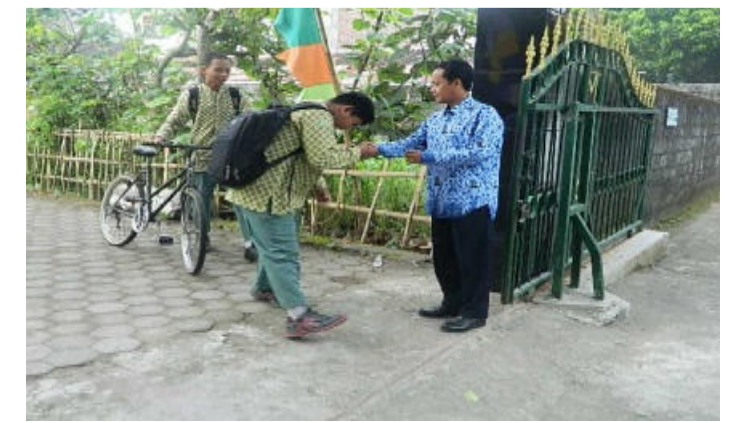

Gambar 1. Mengucapkan salam dan bersalam salaman

2) Berdoa dan membaca asmaul husna

Setelah bel masuk berbunyi seluruh siswa masuk kekelasnya masing-masing dengan tertib, kemudian mereka bersama-sama dikomando ketua kelas melantunkan asmaul husna yang dipimpin langsung oleh guru yang piket dari pusat suara melalui pengeras suara yang bisa didengarkan dikelas masing-masing.

Berdasarkan dari visi-misi madrasah ini beriman dan bertaqwa serta berakhak mulia dengan mengumandangkan asmaul husna menjadikan madrasah ini memiliki ciri khas yang islami.

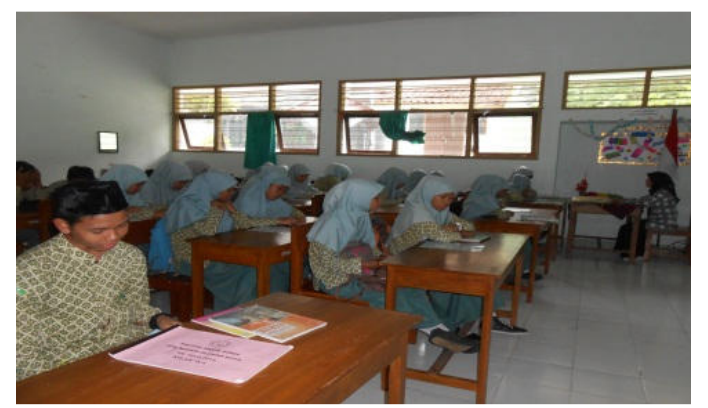

Gambar 2. Membaca Asmaul Husna

3) Tadarus Al-Qur'an

Kegiatan ini dilakukan setelah shalat dzuhur dengan membaca surat dan ayat al- 
Quran yang sudah ditentukan oleh madrasah yang bersinergi dengan tujuan pembejaran agama. Kegiatan ini bertujuan agar siswa terbiasa membaca al Quran disekolah maupun dirumah. Kegiatan ini mampu menghantarkan siswa memiliki karakter yang religius yang senantiasa beriman dan bertaqwa dan berteman dengan qur'an.

4) Shalat dhuha berjamaah

Kegiatan harian ini dilaksanakan pada jam istirahat pertama, yang dilaksanakan dimasjid madrasah dengan dipimpin oleh bapak guru madrasah sebagai imam, dilanjutkan membaca doa setelah sholat dhuha secara bersama-sama. Kegiatan ini diharapkan mampu memunculkan karakter disiplin dan religius terhadap siswa.

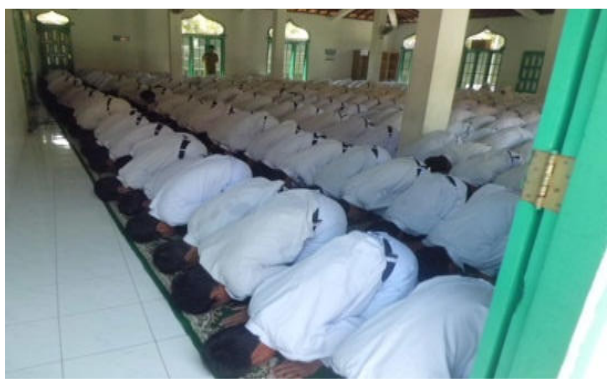

\section{Gambar 3. Pelaksaan shalat dhuha berjamaah}

5) Shalat dzuhur berjamaah

Shalat merupakan salah satu cara hamba berkomunikasi dengan sang pemilikNya. Karna kegiatan ini merupakan budaya madrasah tanpa dikomando seluruh siswa ketika istirahat kedua langsung antri mengambil air wudhu untuk segera melaksanakan sholat dzuhur berjamaah, pembiasaan ini diharapkan mempu menumbuhkan karakter siswa yang religius, senantiasa beriman dan bertaqwa sehingga mampu menumbuhkan suatu kebutuhan terhadap suatu kewajiban, seperti menjalankan shalat dzuhur contohnya.

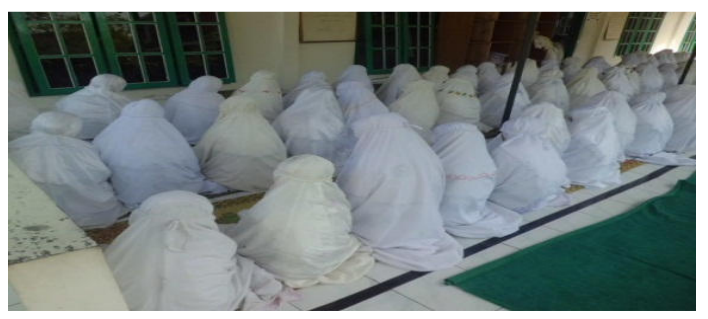

Gambar 4. Pelaksaan shalat dzuhur berjamaah

2. Kegiatan Mingguan

a. Shalat jumat berjamaah dan keputrian

Setiap hari jumat seluruh siswa putra diwajibkan shalat jumat dilingkungan madrasah, dan kegiatan keputrian untuk siswi putri yang diisi dengan kajian keagamaan tentang fiqih wanita dan ketrampilan wanita lainnya.

b. Infaq

Kegiatan infaq ini biasanya dikordinasi oleh ketua kelas, ketua kelas mengambil kotak infaq kelasnya diruang guru, dan kemudian mengembalikknya lagi ketika semua siswa sudah mengisi kotak infaq tersebut. Dana infaq ini dipergunakan untuk perawatan masjid. Kegiatan ini diharapkan mampu menumpuhkan jiwa kebiasaan bershodaqoh siswa dalam menyisihkan hartanya untuk kegiatan ibadah.

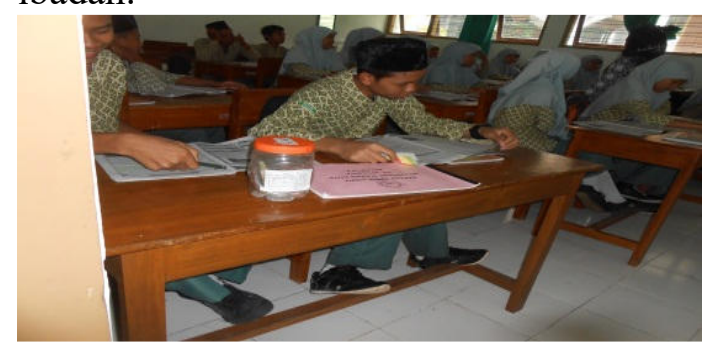

Gambar 5. Kotak infaq yang sedang berada disalah satu kelas 
c. Buku kegiatan siswa

Buku ini merupakan salah satu bentuk pembudayaan agama secara fisik, yang bertujuan sebagai pendampingan shalat dan tadarus siswa saat diluar madrasah. Pengecekan buku ini dilakukan setiap hari sabtu yang disetorkan ke wali kelas dengan sudah ditanda tangani oleh orangtua siswa. Adanya buku ini bertujuan untuk melatihan kejujuran siswa dalam meningkatan karakter religiusitas siswa.

\section{Kegiatan tahunan}

Kegiatan tahunan yang dilaksanakan dlam rangka mensukseskan pembiassan pembudayaan agama terhadap siswa di MTs ini adalah dengan selalu melaksanakan kegiatan peringatan hari besar Islam (PHBI) dengan berbagai kegiatan, lomba-lomba kegaiatan keagaamaan seperti lomba adzan, lomba kaligrafi, tilawah, bahkan lomba hadroh antar kelas, yang biasanya ditutup dengan tabligh akbar dengan mendatangkan ustad untuk mengisi ceramah dalam kegiatan ini, dimaksudkan dalam kegiatan peringatan hari besar ini adalah agar siswa lebih mengerti sejarah Islam yang Indah dan kita wajib mensyukurinya dengan memperingatinya sebagai pengingat. Dan diharapkn mampu menumbuhkan keimanan dan ketaqwaan kepada Allah swt.

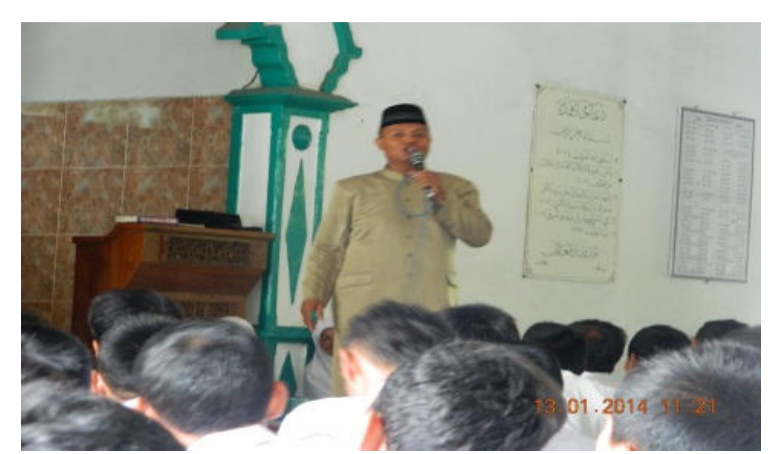

Gambar 6. Salah satu kegiatan PHBI

\section{Pembudayaan agama melalui artefak}

Bentuk pembiasaan budaya yang lain selain dengan kegiatan-kegiatan, di madrasah ini juga terdapat artefak-artefak yang diletakkan di lingkungan madrasah yang strategis dan mudah dibaca oleh setiap siswa dan tamu yang berkunjung sebagai motivasi dan pengingat, seperti jargon-jargon penyemangat, doa-doa harian, asmaul husna serta tata tertib berbusana syari. Pemasangan artefak ini secara tidak langsung sebagai bukti bahwa madrasah ini mendukung kegiatan pembiasaan pembudayaan agama terhadap siswanya dan seluruh civitas madrasah ini. Artefak ini terlihat sederhana namun secara tidak langsung mampu menumpuhkan minat baca terhadap siswanya. Melalui artefak-artefak ini diharapkan mampu menumbuhkan pembiasaan minat baca yang tinggi terhadap siswanya terhadap budaya agama sehingga mampu menumbuhkan karakter yang religius terhadap siswa.

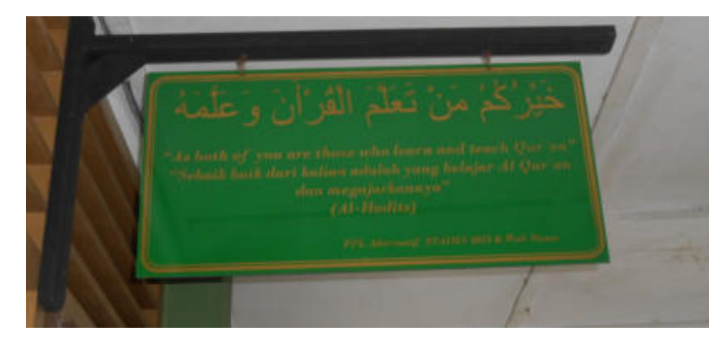

Gambar 7. Salah satu artefak yang ada dilingkungan madrasah 
Hasil pembudayaan agama terhadap karakter siswa di MTsN Sleman Kota Yogyakarta

Dari bentuk-bentuk pembudayaan yang telah dijelaskan dapat ditarik kesimpulan bahwa pembudayaan yang dilaksanakan di Madrasah ini dapat membentuk karakter peserta didik. Ada beberapa nilai karakter yang dikembangkan melalui pembiasaan pembudayaan agama di MTsN Sleman Kota ini sebagai berikut:

\section{Tabel 1. Hasil penmbiasaan budaya}

\begin{tabular}{|c|c|c|}
\hline No & Karakter & Kategori \\
\hline 1 & Religius & $\begin{array}{l}\text { Beriman dan } \\
\text { bertaqwa } \\
\text { Beramal shaleh }\end{array}$ \\
\hline 2 & Disiplin & $\begin{array}{l}\text { Jujur dan tanggung } \\
\text { jawab } \\
\text { Rendah hati } \\
\text { Dalam menggunakan } \\
\text { waktu, disiplin untuk } \\
\text { beribadah dan } \\
\text { menaati peraturan } \\
\text { sekolah }\end{array}$ \\
\hline $\begin{array}{l}3 \\
4\end{array}$ & \multicolumn{2}{|c|}{$\begin{array}{l}\text { Kebersihan dan kerapihan diri } \\
\text { Peduli Lingkungan dan kebersihan }\end{array}$} \\
\hline
\end{tabular}

Faktor-faktor pendukung dan penghambat pembudayaan agama dalam pembentukan KotaYogyakarta Faktor yang mempengaruhi pembiasaan budaya agama dalam madrsah ini terdapat dua faktor yaitu faktor internal dan eksternal:

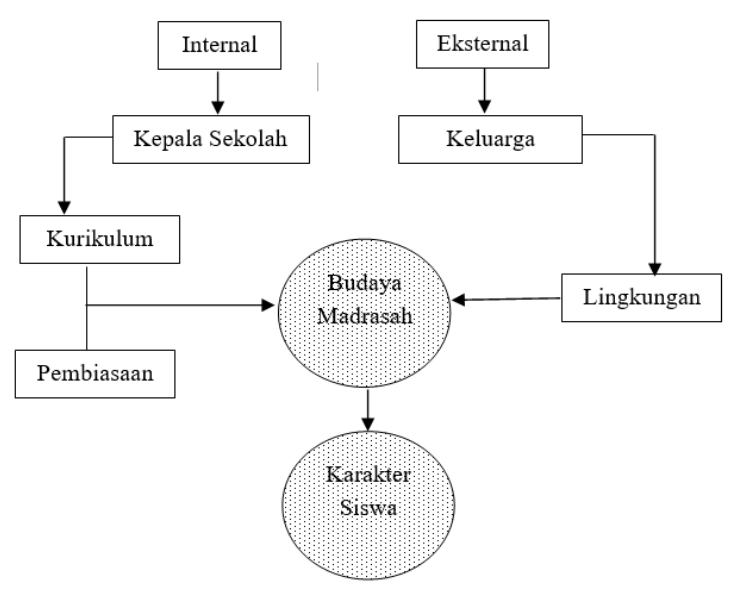

\section{Gambar 8. Faktor-faktor pembentukan pembudayaan agama}

Kedua faktor tersebut saling mendukung terciptanya budaya madrasah yang dapat menciptakan suatu produk yaitu pembentukan karakter siswa dengan budaya madrasah yang melekat pada diri siswa. Dalam melaksanakan pembudayaan agama dalam pembentukan karakter siswanya terdapat beberapa kekuatan yang mendukung pelaksanaan pembudayaan agama:

1. Lingkungan madrasah ini yang memiliki pembiasaan pembudayaan agama yang baik, yang dapat membentuk akhlakul karimah yang baik terhadap peserta didik.

2. Pengelola sekolah dan wali siswa yang bekerjasama dengan baik, sehingga mampu mewujudkan budaya agama yang baik terhadap peserta didik

3. Sarana dan prasarana yang mendukung untuk menjalankan program pembiasaan budaya agama.

Namun selain itu juga ada kelemahan dalam pelaksanaan pembudayaan agama ini, antara lain siswa di madrasah ini yang berasal dari berbagai karakter dan pembiasaan yang berbeda-beda di dalam lingkungan rumahnya, sehingga ketika peran orangtua tidak ikutserta aktif membiasakan dirumah budaya yang diwajibkan dimadrasah 
akan menghambat perwujudan visi dan misi pembudayaan agama terhadap peserta didik. Karena tidak sedikit dari wali siswa yang hanya mempercayakan kepada guru saja tanpa mengontrol kembali pembiasaan agamanya dilingkungan rumah.

Melihat dari hal tersebut mungkin akan lebih sempurna dalam pembudayaan agama terhadap peserta didik ketika mereka mendapatkan dukungan komitmen dari orangtua, jadi pihak sekolah harus menghimbau seluruh wali siswa yang menyekolahkan anaknya di madrasah ini untuk berkomitmen melaksanakan pembiasaan budaya agama dirumah. Kemudian memberikan rewad dan punishman kepada seluruh civitas akademik dilingkungan madrasah yang tidak melaksanakan pembudayaan agama ini.

\section{SIMPULAN}

Setelah melakukan penelitian di Madrasah Tsanawiyah Negeri Sleman Kota Yogyakarta penulis menyimpulkan, bahwa dalam pembentukan karakter siswa di madrasah ini menggunakan suatu proses pembudayaan agama atau pembiasaan penerapan kegiatan keagamaan seperti membiasakan diri untuk mengucapkan salam dan berjabat tangan, sholat dhuha dan dzuhur berjamaah dimadrasah, membaca asmaul husna dan doa bersama sebelum memulai kegiatan, tadarus alQuran dengan ayat-ayat yang telah disesuaiakn dengan konsep pendidikan, shalat jumat dimadrasah, infaq, kegiatan keputrian dan peringatan hari besar Islam serta pembudayaan artefak-artefak agama. Hasil dari pembudayaan agama ini dapat membentuk beberapa karakter siswa antara lain religius, disiplin, kebersihan dan kerapihan diri dan peduli lingkungan dan peduli sosial.

\section{DAFTAR PUSTAKA}

[1] Undang-undang nomor 20 pasal 3 tentang Sistem Pendidikan Nasional. Jakarta: Depdiknas,2000.

[2] Koetjaningrat. Pengantar Ilmu Antropologi. Jakarta: Rineka Cipta,1990.

[3] Muhaimin. Rekontruksi Pendidikan Islam (dari paradigma pengembangan manajemen kelembagaan, kurikulum hingga strategi pembelajaran). Jakarta: Raja Grafindo Persada, 2009.

[4] Tim Departemen Agama RI Direktorat Jendral Kelembagaan Agama Islam. Al qur'an dan terjemaahannya. Jakarta: Depag RI, 2005.

[5] Sugiyono. Metode Penelitian Kuantitatif, kualitatif, R \& D. Bandung: Alfabeta,2009.

[6] Baya Umar, Agus. Pembentukan Karakter Melalui Pendidikan Di Pondok Pesantren Wahid Hasim Yogyakarta. Tesis: Yogyakarta,2013.

[7] Dimas, Aditya. Pengumpulan Data. Dalam blogspot.com. diunduh pada 24 Desember 2013

[8] Dokumentasi MTs Negeri Sleman Kota Yogyakarta

[9] Zaenal Fitri, Agus. Pendidikan Karakter berbasis Nilai dan Etika di Sekolah. Yogyakarta:R-ruzz Media, 2012 